\title{
Glands on the foliar surfaces of tribe Cercideae (Caesapiniodeae, Leguminosae): distribution and taxonomic significance
}

\author{
JOAQUIM M. DUARTE-ALMEIDA ${ }^{1,2}$, MILENE S. CLEMENTE ${ }^{1}$, \\ ROSANI C.O. ARRUDA ${ }^{3}$, ANGELA M.S.F. VAZ ${ }^{4}$ and ANTONIO SALATINO ${ }^{1}$ \\ ${ }^{1}$ Instituto de Biociências, Universidade de São Paulo, \\ Rua do Matão, 277, 05508-090 São Paulo, SP, Brasil \\ ${ }^{2}$ Laboratório de Farmacognosia/Produtos Naturais, Universidade Federal de São João Del Rei, \\ Rua Sebastião Gonçalves Coelho, 400, 35501-296 Divinópolis, MG, Brasil \\ ${ }^{3}$ Centro de Ciências Biológicas e da Saúde, Universidade Federal de Mato Grosso do Sul, \\ Av. Sen. Felinto Muller, s/n, Cidade Universitária, 79070-900 Campo Grande, MS, Brasil \\ ${ }^{4}$ Diretoria de Pesquisas do Jardim Botânico do Rio de Janeiro (DIPEQ/JBRJ), \\ Rua Pacheco Leão, 915, 22460-030 Rio de Janeiro, RJ, Brasil \\ Manuscript received on March 31, 2014; accepted for publication on October 24, 2014
}

\begin{abstract}
Large elongated glands occur on Cercideae leaf surfaces. Leaves of Bauhinia (55 taxa, 53 species), Cercis (1 species), Phanera (1 species), Piliostigma (2 species), Schnella (19 species) and Tylosema (1 species) were observed to determine location and relative number of glands. They were only observed on the abaxial leaf surface of 42 Bauhinia taxa. The glands were analyzed by light stereomicroscope and scanning electron microscopy. They are large (up to $270 \mu \mathrm{m}$ long and $115 \mu \mathrm{m}$ wide) and multicellular, containing lipophilic substances, probably volatile oils. Presence or absence and density of the glands in species of Bauhinia may be useful to determine species delimitation or distinction among infraspecific taxa. Higher density of glands is more common in species from "cerrado" (a savanna ecosystem) and "caatinga" (a semiarid ecosystem from northeast Brazil) areas. Bauhinia species devoid of foliar glands are frequently from humid forests.
\end{abstract}

Key words: Bauhinia, Brazilian forest, Leguminosae, secretory structure, taxonomy, tropical ecosystems.

\section{INTRODUCTION}

Studies aboutsecretory structures are valuable for many fields of plant biology. Some examples of such studies and corresponding objectives are: 1) identification or assignment of classes of substances produced and accumulated (Roshchina and Roshchina 1993); 2) test of hypotheses about their adaptive and physiological roles (Farrell et al. 1991); and 3) evaluation of their

Correspondence to: Joaquim M. Duarte-Almeida

E-mail:maudall@ufsj.edu.br taxonomic significance (Sartori and Tozzi 2002). Secretory structures consist of highly specialized cells involved in the synthesis and secretion, and in some cases reabsorption of substances, often corresponding to secondary metabolites (Esau 1977, Fahn 1979, Roshchina and Roshchina 1993). Secretory structures may occur on foliar surfaces of some taxa of Fabaceae, such as species of the tribe Caesalpinieae (Lersten and Curtis 1996) and of the genus Chamaecrista (Conceição et al. 2009). 
Bauhinia sensu lato is a large genus of Caesalpinioideae (Leguminosae) that is widely distributed in tropical and subtropical regions of the New and Old Worlds. Several of its species, commonly called "orchid trees", are praised for their floral beauty. A flower of B. blakeana is displayed on the regional flag of Hong Kong. $B$. acuminata, B. blakeana, B. galpinii, B. monandra, $B$. purpurea, $B$. tomentosa and $B$. variegata are cultivated as ornamental trees worldwide, specially in warm countries. In several parts of the world, Bauhinia species are used in popular medicine to control levels of glucose in the blood (Menezes et al. 2007, Cechinel 2009). Many species of Bauhinia are easily recognized by their commonly bilobed leaves and palmate-arcuate leaf veins. The genus Bauhinia was placed as a member of Cercideae, together with Adenolobus, Griffonia and Cercis by Wunderlin et al. (1981, 1987). However, the traditional delimitation of Bauhinia has been questioned. Queiroz (2006) and Vaz (2010) recognized Phanera as distinct from Bauhinia, pointing out distinctive vegetative and floral characters. Lewis and Forest (2005) hypothesized that Bauhinia sensu Wunderlin et al. (1987) (i.e., Bauhinia s.1.) is paraphyletic and suggested that a detailed revision of the group was needed. They proposed the division of Bauhinia s.l. into 8 genera: Bauhinia s. str. (150-160 species), Gigasiphon (4-5 species), Tylosema (4 species), Barklya (1 species), Lysiphyllum (8 species), Phanera (120130 species), Lasiobema (15-20 species) and Piliostigma (3 species). Lewis and Forest (2005) observed that Lasiobema appears least well supported and that Schnella might prove to be distinct from Phanera. A molecular phylogenetic analysis of Bauhinia s.l. by Sinou et al. (2009), based on the plastid DNA region trn L-trnF, yielded two large sister clades, one comprising the genera Gigasiphon, Lysiphyllum, Phanera, Barklya and Tylosema, and another embracing Piliostigma, Breniera and Bauhinia s.str. In addition, this analysis indicates that Phanera is polyphyletic, with the Asian species emerging together with Lasiobema and the American species forming another clade (= Schnella). In a reorganization of the Cercideae, Wunderlin (2010) divides the tribe into the subtribes Cercidiinae and Bauhiniinae. The former comprises the genera Cercis (6 species), Adenolobus (2 species) and Griffonia (4 species). The subtribe Bauhiniinae contains the genera Bauhinia (150-160 species), Barklya (1 species), Brenierea (1 species), Gigasiphon (5 species), Lysiphyllum (9 species), Phanera (Asian, 90100 species), Piliostigma (5 species), Schnella (American Phanera, 40 species) and Tylosema (4 species). The present paper follows this taxonomic alignment for Cercideae, including reference for South American species under Piliostigma.

In Brazil, there are approximately 100 species of Cercideae (Rodrigues and Vaz 2008). They correspond mostly to Bauhinia and Schnella, plus a few species of Bauhinia sect Benthamia (Fortunato and Wunderlin 1985), here included under Piliostigma (see footnote in Table SI) (Supplementary Material). The species are distributed in nearly all ecosystems, including forests (Amazonian, Atlantic, gallery forests), savannas (cerrados, campos rupestres) and caatinga (dry deciduous forest of the semi-arid Brazilian Northeast) (Vaz and Tozzi 2003, 2005). Species of Bauhinia and Piliostigma are trees and shrubs lacking tendrils, whereas species of Schnella are lianas and vines with tendrils.

An unusual kind of multicellular secretory structure, which is known as either a "boat-shaped" gland (Solereder 1908, Metcalfe and Chalk 1950) or an "inflated" trichome (Tucker et al. 1984), was observed on leaf surfaces of Bauhinia.

We hypothesize that the presence of such glands may be a morphological character of taxonomic use for distinguishing amongst some taxa of Cercideae. Therefore, the present work aims to show the foliar glands of species of Cercideae and investigate 
their distribution and density on leaves in order to evaluate their distribution and possible taxonomic significance. In an attempt to detect differences in the density of glands among Brazilian species from distinct ecosystems, attention was given to habitat preferences of species.

\section{MATERIALS AND METHODS}

\section{TAXA SAMPLING}

Figure 1 presents the affinity relationships within Cercideae and indicates which groups of the tribe are represented in the present work. Table SI lists specimens analyzed and corresponding vouchers. In the present work, 55 taxa of the genus Bauhinia, 1 of Cercis, 2 of Piliostigma, 19 of Schnella and 1 of Tylosema were analyzed. For anatomical analyses by light and scanning electron microscopy, fresh, adult and fully expanded leaves of $B$. aculeata, B. brevipes, B. forficata, B. longifolia and B. rufa were collected and fixed in the field. Samples of other species were obtained from the herbaria of the Institute of Biosciences, University of São Paulo (SPF) and of the Botanical Garden of Rio de Janeiro (RB). Voucher specimens of all species studied are deposited in SPF and RB and listed in Table SI.

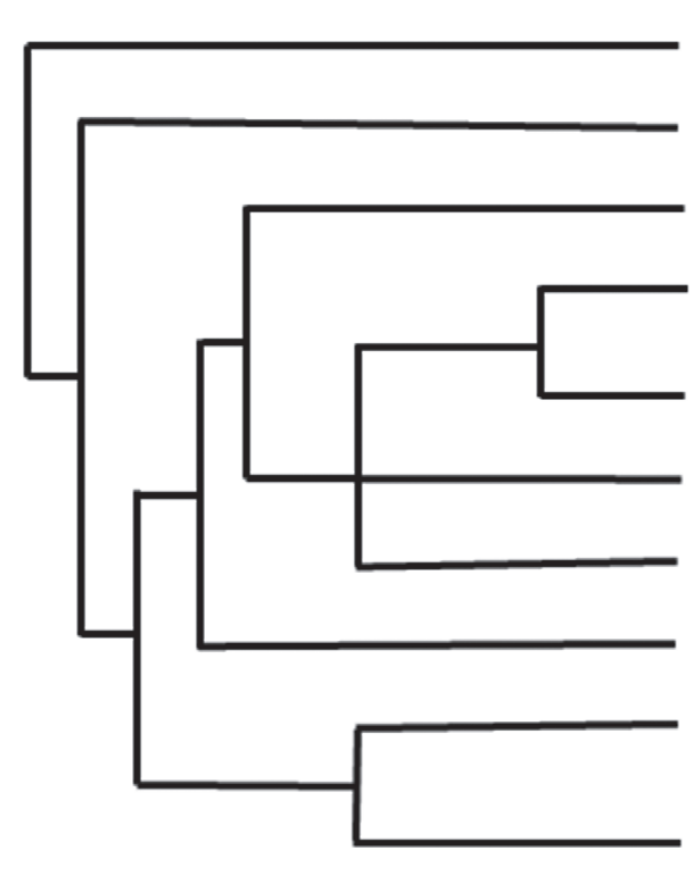

\section{Cercis (R)}

Adenolobus (NR)

Gigasiphon (NR)

Lysiphyllum (NR)

Lasiobema + Asian Phanera (NR)

Schnella (American Phonera) (R)

Barklya (R)

Tylasema (R)

Plinastigma (R)

Bauhinia s.str. (R)

Figure 1 - Simplified phylogenetic relationships among groups of Cercideae, based on Sinou et al. (2009). NR and R: taxa not represented and represented, respectively, in the present work; s. str.: sensu stricto.

\section{ANATOMICAL STUDIES}

Fresh leaves were fixed in CRAF III (Johansen 1940), hand-sectioned and dehydrated in ethanol series. The epidermis was studied using leaf sections cleared with $10 \%$ aqueous $\mathrm{NaClO}_{4}$. Both materials (epidermis clearings and leaf cross sections) were stained with Sudan IV (a lipophilic dye), wholemounted in glycerine: water (1:1) (Sass 1951) and analyzed with a Vanox AHB-LB Olympus microscope (Olympus Co., Tokyo, Japan). 
SCANNING ELECTRON MICROSCOPY (SEM)

For scanning electron microscopy, fixed leaves were dehydrated in graded ethanol series, submitted to critical point drying with $\mathrm{CO}_{2}$ (Leica EM CPD030, Leica Microsystems, Heerbrugg, Switzerland), mounted on stubs, and coated with gold-palladium (Berlyn and Miksche 1976). The preparations were examined with a Zeiss DSM-940 SEM (Karl Zeiss, Oberkochen, Germany).

IMAGE PROCESSING

Glands on leaves of herbarium specimens were observed and photographed with a Canon Rebel XT digital camera (Canon Inc., Tokyo, Japan), equipped with a $100 \mathrm{~mm}$ close-up lens and $68 \mathrm{~mm}$ extension tubes.

Leaves of herbarium specimens of all material listed in Table SI were observed with light reflected from abaxial leaf surfaces, using a stereomicroscope Leica DMLB (Leica Microsystems, Heerbrugg, Switzerland). IM50 software (Leica) was used for direct observation and image processing. For each taxon, the presence and density of glands were examined on the surface of three fully expanded leaves of each specimen. The number of glands was counted in five squares of $2.3 \mathrm{~mm} \times 1.8 \mathrm{~mm}$ randomly selected on the lower third of the abaxial face of one of the leaves, paying particular attention to veins, intervenal spaces and margins.

\section{RESULTS}

\section{LEAF GLANDS: MORPHOLOGY AND CONTENT}

Leaf glands of Bauhinia are elongated and emerge from the abaxial surface on a short multicellular stalk (Fig. 2A). A large internal space is visible in transversal and longitudinal sections of the glands (Fig. 2A). The glands are formed by a single layer of cells surrounding a cavity that accumulates oil (Figs. 2A, C).

Gland contents are usually lost after fixation and by procedures to prepare histological sections in Paraplast ${ }^{\circledR}$ or historesin. Hence, in this investigation, hand sections fixed in CRAF III (Johansen 1940) were used for histological observation. Reflecting strong staining by Sudan IV, the secretion inside the glands is oily. Glands of clarified leaves treated with Sudan IV exhibit a spherical lipophilic content (Fig. 2B). A similar content is observed in non-sectioned glands (Fig. 2C). Viewed by scanning electron microscopy, the cells delimiting the glands have no surface ornamentation and are elongated along the longer axis of the glands (Figs. 3C-E). Glands are visible near the margin of the lamina in $B$. aculeata (Fig. 2D). Glands are variable in size in Bauhinia. In some species, such as $B$. variegata, they are long and slender, up to $200 \mu \mathrm{m}$ long and $30 \mu \mathrm{m}$ wide. In $B$. pentandra, however, they are much shorter, $95 \mu \mathrm{m}$ long and $35 \mu \mathrm{m}$ wide. The largest glands were observed on leaves of B. subclavata, reaching up to $270 \mu \mathrm{m}$ in length and $115 \mu \mathrm{m}$ in width; the smallest were on leaves of $B$. campestris, $50 \mu \mathrm{m}$ long and $27 \mu \mathrm{m}$ wide. Leaves of several species of Bauhinia have thick, profusely fibrous veins, which protrude from the abaxial surface forming deep ridges, delimiting intervenous regions where cells, frequently papillate, constitute the epidermis (Figs. 2A, 3A-C). Quite often these intervenous regions have many non-glandular trichomes (Figs. 2B, 3AC), among which glands may be nested (Figs. 2A, $\mathrm{D}, 3 \mathrm{~B})$. In some species, such as $B$. brevipes, the glands are elliptical (Fig. 3B). In other species, such as $B$. forficata, they are long and slender (Fig. $3 C)$. In B. aculeata, the glands are wider at one end and narrower at the other (Figs. 3A, E), while other species (e.g., B. longifolia) have broad cylindrical glands (Fig. 3D). Glands of B. bombaciflora are spread uniformly on the leaf lamina (Fig. 4A), while the glands are restricted to the leaf margin on leaves of $B$. galpinii (Fig. 4B). Figure 4C shows the abaxial surface of a $B$. ovata leaf obtained with reflected light by stereomicroscopy; glands are seen to be spread evenly on the foliar lamina. A foliar gland of B. subclavata observed with higher magnification is seen in Fig. 4D. 

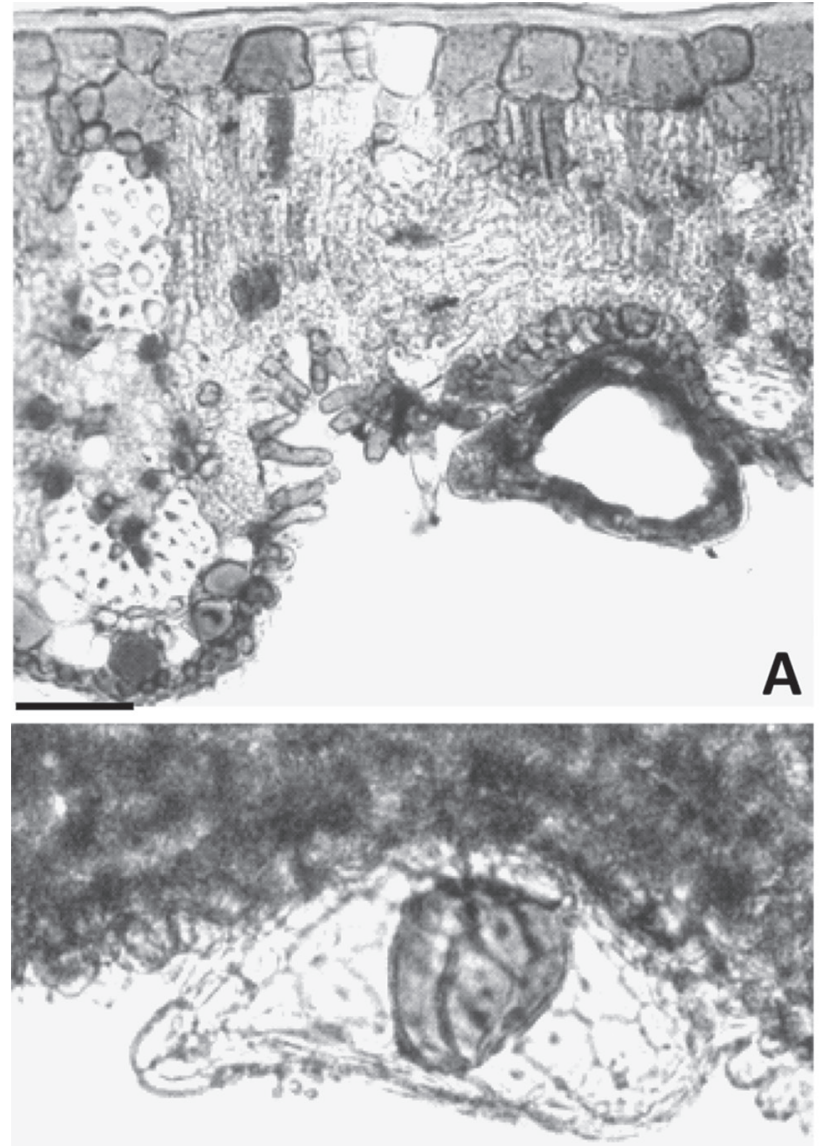

C
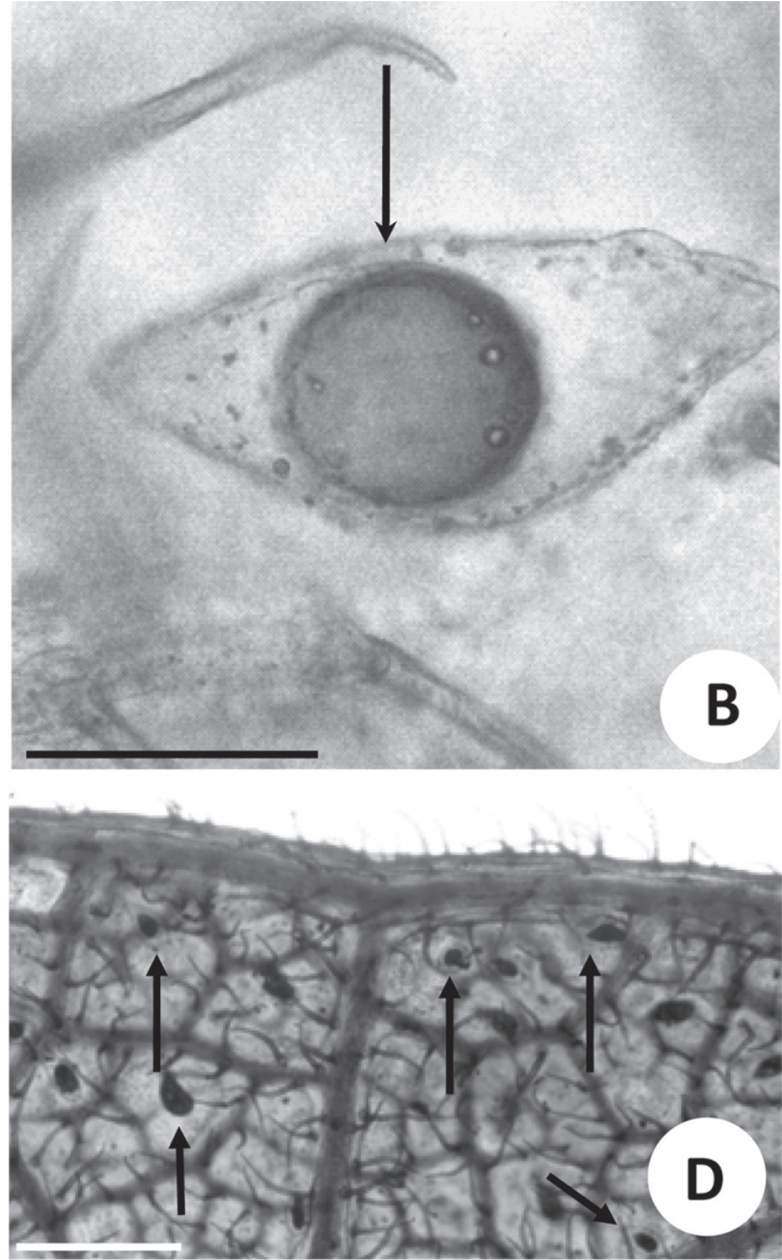

Figure 2 - Glands seen in light microscopy. (A) Transversal section of the leaf blade of Bauhina rufa (SPF 79418), showing a gland inserted in an intervenal region, scale bar $=50 \mu \mathrm{m}$. (B) Segment of cleared leaf showing lipid content inside a gland of $B$. brevipes (SPF 142960) and non-glandular trichome (arrow), scale bar $=100 \mu \mathrm{m}$. (C) Transversal section of leaf blade of $B$. brevipes, showing a gland in lateral view inserted in a small depression on the abaxial surface with a lipid drop visible inside, scale bar $=100 \mu \mathrm{m}$. (D) Segment of a cleared leaf of B. aculeata (RB 94867) showing glands (arrows) distributed in intervenal regions, scale bar $=400 \mu \mathrm{m}$.

\section{DENSITY OF GLANDS}

Table SI details the relative density of glands and their preferential distribution on the leaf lamina. No glands were observed on leaves of the studied species of Cercis, Schnella and Piliostigma. In the genus Bauhinia, 42 specimens studied possessed glands and 12 lacked them (Table SI). Density of glands on leaf surfaces varies widely. Glands can be extremely rare (e.g., $B$. bauhinioides, $B$. macranthera, $B$. marginata,) or very numerous, for example, up to 36 glands per square millimeter on leaves of B. campestris and 55 on leaves B. tenella. When glands are rare, they are likely to be restricted to the margins and veins (e.g., B. bauhinioides, B. cinnamomea, B. pentandra, B. pulchella, $B$. purpurea, B. rufa, B. subrotundifolia, B. ungulata var. ungulata and $B$. variegata). Margins and veins appear to have more glands than other leaf parts in some species with high gland density (e. g., $B$. cheilantha and B. membranacea). 


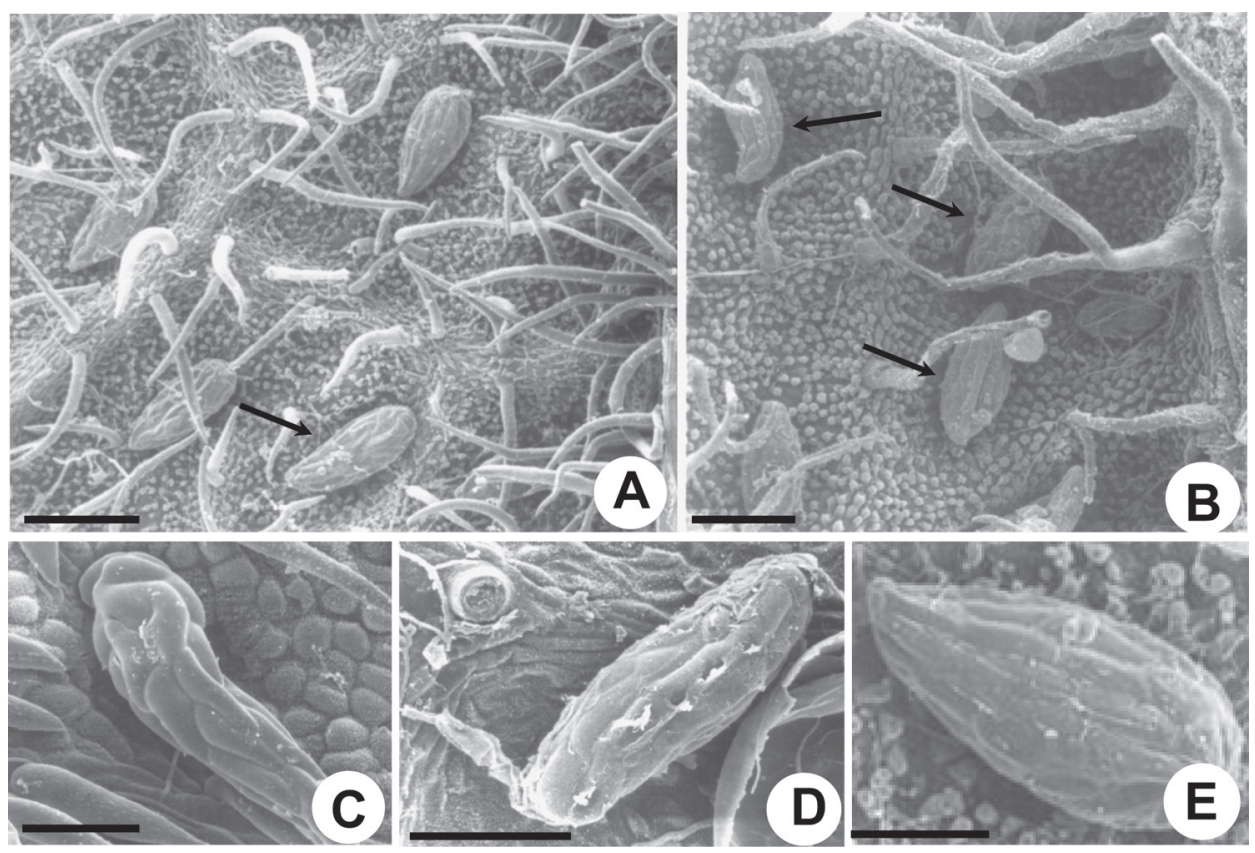

Figure 3 - Scanning Electron Microscopy of leaf surface of subgenus Bauhinia. (A) Abaxial side of leaf of B. aculeata (RB 94867) with glands (arrows) and non-glandular trichomes, scale bar $=150 \mu \mathrm{m}$. (B) Glands (arrows) at the base of a depression formed by protruding veins (left) of $B$. brevipes (SPF 142960), and papillate epidermal cells also can be seen, scale bar $=50 \mu \mathrm{m}$. (C) Detail of a gland on the abaxial surface of a leaf of $B$. forficata, scale bar $=50 \mu \mathrm{m}$. (D) Secretory gland of B. longifolia (SPF 122376), scale bar $=50 \mu \mathrm{m}$. (E) Detail of a single gland of B. aculeata (RB 94867), scale bar $=50 \mu \mathrm{m}$.

\section{DISCUSSION}

Glandular secretory structures are taxonomically meaningful. For example, spherical ethereal oil cells characterize Piperaceae, and secretory schizogenous and lysigenous cavities characterize Myrtaceae and Rutaceae, respectively, while shizogenous secretory canals and glandular trichomes are typical of Apiaceae and Lamiaceae, respectively (Cronquist 1981). At lower hierarchic level, schizogenous secretory cavities enable distinction between Dahlstedtia pentaphylla and D. pinnata Fabaceae, Caesalpinioideae (Teixeira and Rocha 2009) and between the subgenera Lonchocarpus and Punctati of the genus Lonchocarpus - Fabaceae, Papilionoideae (Teixeira et al. 2000).

Lersten and Curtis (1996) described foliar surface glands of species of Caesalpinieae. Marquiafável et al. (2009) recognized seven types of glands that may appear on the surface of reproductive and vegetative organs of Indigofera (Leguminosae, Papilionoideae). Type 3 resembles the glands described in the present work: they have a short peduncule and a curved and oval head. But unlike the glands of Bauhinia, Indigofera type 3 glands have massive head. In addition, Bauhinia glands are longer than Indigofera type 3.

GLANDS AND ENVIRONMENTAL CONDITION

The glands described in the present work are confined to the abaxial leaf surface of the majority of species of Bauhinia. The material contained in the glands is probably volatile oil. Several lines of evidence lead to this assumption. First, the secretion is lipophilic, as shown by Sudan staining. Second, Duarte-Almeida et al. (2004) reported the content and composition of volatile oils from leaves of $B$. 

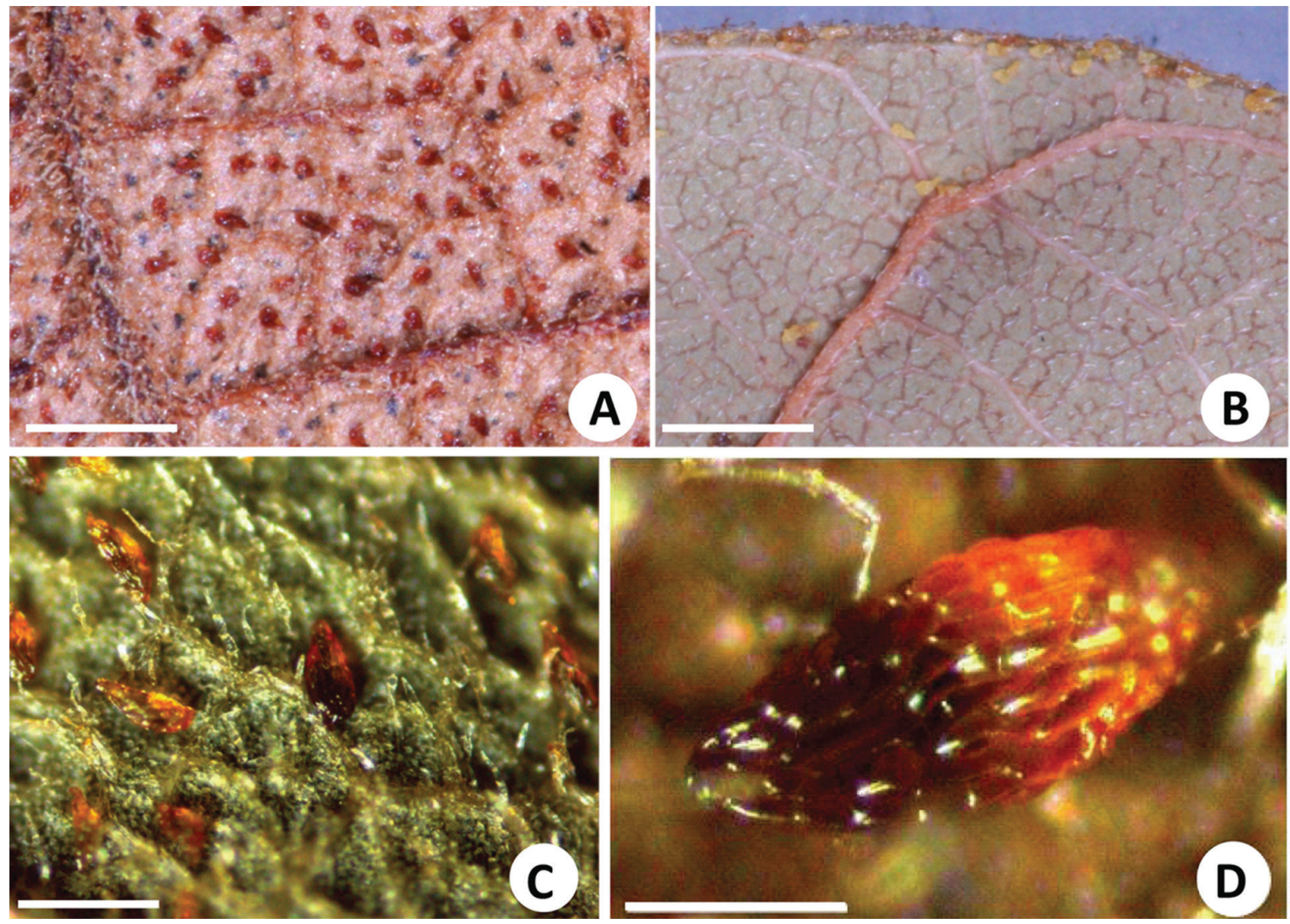

Figure 4 - Abaxial surfaces of leaves of species of subgenus Bauhinia. (A) B. bombaciflora (RB 213381), scale bar=1 mm. (B) B. galpinii, scale bar $=1 \mathrm{~mm}$. (C) B. ovata (SPF 95043), scale bar $=100 \mu \mathrm{m}$. (D) B. subclavata (RB 312959), scale bar=200 $\mu \mathrm{m}$. Images obtained with digital camera and close-up lens (A and $\mathbf{B})$ and stereomicroscope and computer processing $(\mathbf{C}$ and $\mathbf{D})$.

aculeata, B. brevipes, B. forficata, B. longifolia, $B$. pentandra, $B$. rufa and $B$. variegata. As seen in Table SI, the leaves of all these species possessed glands. Third, two species examined by DuarteAlmeida et al. (2004) failed to yield volatile oils: Schnella alata and S. outimouta (syn. Bauhinia alata and B. outimouta, respectively). Neither of the species exhibited foliar surface glands in the present investigation (Table SI).

IMPLICATIONS FOR TAXONOMY

Our results indicate that foliar surface glands are useful to distinguish the genus Bauhinia from Cercis, Piliostigma, Schnella and Tylosema. Cercis is basal in the Cercideae phylogeny (Sinou et al. 2009). Cercis, plus Adenolobus, Griffonia and the large clade embracing Gigasiphon, Lysiphyllum,
Lasiobema, Asian Phanera, "American Phanera" (= Schnella), Barklya and Tylosema, possess the intron $r p L 2$. Loss of the intron is assumed by Sinou et al. (2009) to be a synapomorphy of the clade comprising Piliostigma, Brenierea and Bauhinia. As such, Piliostigma lacks both the $r p L 2$ intron and foliar glands, whereas Bauhinia lacks the intron, but possesses foliar glands. The presence of glands appers to be a possible a synapomorphy of the Bauhinia clade. The glands are present in several internal clades of Bauhinia, such as the two clades corresponding to section Pauletia (e.g., B. pulchella and $B$. aculeata), the clade of section Bauhinia (e.g., B. dipetala), or the polytomy corresponding to section Telestria (e.g., B. variegata). Absence of glands in the genus (Table SI) may represent cases of homoplasy by reversal. 
High density of glands was observed on leaves of species of Bauhinia from the cerrado and caatinga vegetation, as described above. The highest density, 55 glands $/ \mathrm{mm}^{2}$, was found in $B$. tenella, a species typical of the cerrado (Table SI). Values up to 24, 26 and 36 glands $/ \mathrm{mm}^{2}$ were registered for B. curvula, B. bombaciflora and $B$. campestris, all species from the cerrado (Table SI). Leaves of B. subclavata, a species occurring in the cerrado and the caatinga, may have 15 glands $/ \mathrm{mm}^{2}$ (Table SI). Leaves of species typical of the caatinga, such as B. cacovia, B. cheilantha and $B$. corifolia, also have relatively high gland density on the leaf lamina (13, 15, and 10 glands/ $\mathrm{mm}^{2}$, respectively; Table SI). Among species with leaves devoid of glands, only B. dubia occurs in the cerrado and the caatinga, but also in humid forests. Species of Bauhinia without glands seem to occur mostly in humid forests. Among the 13 species and one subspecies of Bauhinia studied with leaves on which no glands were found, four are not native to Brazil (B. acuminate, B. dipetala, B. monandra and B. tomentosa), and eight occur in humid forests. Some species of Bauhinia from humid forests do have leaves with glands (e.g., $B$. aureopunctata, B. cinnamomea, B. corniculata, $B$. fusconervis and B. ovata), although these are mostly species with low gland density (Table SI).

\section{GLANDS: POTENTIAL TAXONOMIC IMPLICATIONS}

Presence of glands in Cercideae may be taxonomically useful at the genus level. Within Bauhinia, the gland density seems to be ecologically related. Vaz and Tozzi (2003) recognized $B$. holophylla, B. longifolia and $B$. rufa as a species complex sharing several morphological characters. Leaves of both $B$. holophylla and B. rufa have a relatively high density of glands on the leaf lamina and margin (Table SI). They differ, however, from leaves of $B$. longifolia which has low gland density, restricted to the margins or veins. B. holophylla and $B$. rufa are frequent in dry savannas and rarely occur in humid forests, while the opposite applies to B. longifolia. Presence or absence of glands in Bauhinia may also be taxonomically useful for distinguishing among infraspecific taxa. Two specimens of $B$. forficata were analyzed in the present work: SPF 34660, corresponding to a specimen of the type subspecies, and SPF 105974 , belonging to $B$. forficata subsp. pruinosa. On the margin of the leaves of subspecies forficata were detected 3-5 glands $/ \mathrm{mm}^{2}$, while no glands were detected on leaves of subspecies pruinosa. $B$. forficata subsp. pruinosa now includes $B$. candicans Benth. in synonymy (Vaz and Tozzi 2005). These observations indicate that presence and density of glands on leaves of Bauhinia may be useful for distinguishing among species or infraspecific taxa.

\section{ACKNOWLEDGMENTS}

The authors thank Gwil P. Lewis (Royal Botanic Gardens, Kew) for critical and helpful comments and Giuliano Locosselli for digital photography. JMDA thanks Coordenação de Aperfeiçoamento de Pessoal de Nível Superior (CAPES, Brazil) for funding. AS is a Research Fellow of Conselho Nacional do Desenvolvimento Científico e Tecnológico (CNPq, Brazil).

\section{RESUMO}

Glândulas alongadas ocorrem em superfícies foliares de Cercideae. As folhas de Bauhinia (55 táxons, 53 espécies), Cercis (1 espécie), Phanera (1 espécie), Piliostigma (2 espécies), Schnella (19 espécies) e Tylosema (1 espécie) foram observadas para determinar a distribuição e número relativo de glândulas. Elas foram observadas apenas na face abaxial das folhas de 42 espécies de Bauhinia. As glândulas foram analisadas em microscópio estereoscópico e microscópio eletrônico de varredura. Elas são multicelulares, com grandes dimensões (acima de $270 \mu \mathrm{m}$ de comprimento e $115 \mu \mathrm{m}$ de largura) e contêm substâncias lipofílicas provavelmente óleos voláteis. A presença ou ausência e a densidade das glândulas em espécies de Bauhinia 
podem ser úteis para determinar a delimitação de espécies ou distinção entre taxa infraspecíficos. As espécies de cerrado (um ecossistema de savana) e de áreas de caatinga (um ecossistema semiárido do nordeste do Brasil) apresentaram maior densidade de glândulas. Espécies desprovidas de glândulas foliares são frequentemente de florestas úmidas.

Palavras-chave: Bauhinia, floresta brasileira, Leguminosae, estruturas secretoras, taxonomia, ecossistema tropical.

\section{REFERENCES}

BERLYN GP AND MiKsCHE M. 1976. Botanical microtechnique and cytochemistry. Iowa States Press, Ames, 336 p.

Cechinel V. 2009. Chemical composition and biological potential of plants from the genus Bauhinia. Phytother Res 23: 1347-1354.

CONCEIÇão AD, QUEIROZ LP, LEWIS GP, ANDRADE MJG AND ALMEIDA PRM, SCHNADELBACH AS AND VAN DEN BERG C. 2009. Phylogeny of Chamaecrista Moench. (Leguminosae - Caesalpinioideae) based on nuclear and chloroplast DNA regions. Taxon 58: 1168-1180.

CRONQUist A. 1981. An integrated system of classification of flowering plants. New York: Columbia University Press, $1626 \mathrm{p}$.

Duarte-Almeida JM, Negri G and Salatino A. 2004. Volatile oils in leaves of Bauhinia (Fabaceae Caesalpinioideae). Biochem Syst Ecol 32: 747-753.

ESAU K. 1977. Anatomy of seed plants, $2^{\text {nd }}$, New York: J Wiley \& Sons, $550 \mathrm{p}$.

FAHN A. 1979. Secretory tissues in plants, London: Academic Press, $302 \mathrm{p}$.

FARRELl BD, DusSOURD DE AND MitTER C. 1991. Escalation of plant defense: do latex and resin canals spur plant diversification? Am Nat 138: 881-900.

FORTUNATO RH AND WUNDERLIN RP. 1985. Benthamia: Una nueva seccion del genero Bauhinia L. (Cercideae, Caesalpinioideae, Fabaceae). Parodiana 3: 317-327.

JOHANSEN DA. 1940. Plant microtechnique. New York: McGraw-Hill Book Company Inc, 523 p.

LERSTEN NR AND CURTIS JD. 1996. Survey of leaf anatomy, especially secretory structures, of tribe Caesalpinieae (Leguminosae, Caesalpinioideae). Plant Syst Evol 200: 21-39.

LEWIS GP AND Forest F. 2005. Tribe Cercideae. In: LEWIS GP, SCHRIRE B, MACKINDER B and LOCK M (Eds), Legumes of the World. Kew: Royal Botanic Gardens, p. 57-67.

MARQuiafável FS, FERREIRA MDS AND TeIXEIRA SP. 2009. Novel reports of glands in Neotropical species of Indigofera (Leguminosae, Papilionoideae). Flora 204: 189-197.
Menezes FDS, Minto ABM, Ruela HS, Kuster RM, SHERIDAN H AND FRANKISH N. 2007. Hypoglycemic activity of two Brazilian Bauhinia species: Bauhinia forficata L. and Bauhinia monandra Kurz. Rev Bras Pharmacogn 17: 08-13.

Metcalfe CR And ChalK L. 1950. Anatomy of the dicotyledons. Oxford: Clarendon Press, $1500 \mathrm{p}$.

QUEIROZ LP. 2006. New species and new combinations in Phanera (Caesalpinioideae, Cercideae) from the caatinga. Neodiversity 1: 6-10.

Rodrigues ACLN AND VAZ AMS. 2008. Bauhinia albicans e $B$. affinis: espécies ameaçadas de extinção no estado do Rio de Janeiro. Rodriguesia 59: 449-454.

Roshchina VV AND RoshchINA VD. 1993. The excretory function of higher plants. Berlin: Spinger-Verlag, $314 \mathrm{p}$.

SARTORI ALB AND TOZZI AMA. 2002. Comparative leaflet anatomy in Myrocarpus Allemão, Myroxylon L. and Myrospermum Jacq. (Leguminosae - Papilionoideae Sophoreae) species. Bot J Linn Soc 140: 249-259.

SASS JE. 1951. Botanical microtechnique, AMES: The Iowa State College, 228 p.

Sinou C, Forest F, Lewis GP AND BRUneau A. 2009. The genus Bauhinia s.l. (Leguminosae): a phylogeny based on the plastid trnL-trnF region. Botany 87: 947-960.

SOLEREDER H. 1908. Systematic anatomy of the dicotyledons, Translated by BOODLE LA AND FRITSH FE, Oxford: Clarendon, $1182 \mathrm{p}$.

TEIXEIRA SP, CASTRO MM AND TOZZI AMGA. 2000. Secretory cavities and pellucid dots in leaflets of Lonchocarpus (Leguminosae, Papilionoideae, Millettieae). Plant Syst Evol 221: 61-68.

TEIXEIRA SP AND Rocha JF. 2009. Oil glands in the Neotropical genus Dahlstedtia Malme (Leguminosae, Papilionoideae, Milletieae). Rev Bras Bot 32: 57-64.

TUCKER SC, RUGENSTEIN SR AND Derstine K. 1984. Inflated trichomes in flowers of Bauhinia (Leguminosae: Caesalpinioideae). Bot J Linn Soc 88: 291-301.

VAZ AMSF. 2010. New combinations in Phanera (Leguminosae: Cercideae) from Brazil. Rodriguesia 61: S33-S40.

VAz AMSF AND Tozzi AMGA. 2003. Bauhinia ser. Cansenia (Leguminosae: Caesalpinioideae) no Brasil. Rodriguesia 54: 55-143.

VAZ AMSF AND TOZZI AMGA. 2005. Sinopse de Bauhinia sect. Pauletia (Cav.) DC. (Leguminosae: Caesalpinioideae: Cercideae) no Brasil. Rev Bras Bot 28: 477-491.

WUNDERLIN R, LARSEN K AND LARSEN SS. 1981. Cercideae. In: POLHILL RM AND RAVEN PH (Eds), Advances in Legume Systematics, Kew: Royal Botanic Gardens, p. 107-116.

Wunderlin R, LARSEN K AND LARSEN SS. 1987. Reorganization of the Cercideae (Fabales: Caesalpiniaceae). Kong Danske Vid Selsk 28: 1-40.

WUNDERLIN RP. 2010. Reorganization of the Cercideae (Fabaceae: Caesalpinioideae). Phytoneuron 48: 1-5. 


\section{SUPPLEMENTARY MATERIAL}

Table SI - Density (glands $/ \mathrm{mm}^{2}$ ) and preferential distribution of surface glands, as observed on abaxial surface of leaves of Cercideae taxa and respective Brazilian ecosystems.

${ }^{1} \mathrm{Ca}$ : caatinga; Cer: cerrado; [Cult]: Cultivated as ornamental tree in Brazil; DcF: deciduous forest; [-]: extra-Brazil species not correlated with ecosystems; HuF: humid forest; *: periodically flooded varzea.
${ }^{2}$ n: none; L: leaf lamina; M: leaf margin; V: vein.

${ }^{3}$ Basionyms are maintained regarding this genus, since no binomials based on Piliostigma have been published after the reorganization of tribe Cercideae (Wunderlin 2010). The species cited above under Piliostigma were included by Wunderlin et al. (1987) under Bauhinia subg. Piliostigma (=Elayuna) sect. Benthamia.

${ }^{4}$ Species names adopted according to the delimitation of Schnella sensu Wunderlin (2010). 